\title{
A Study of College Level Academic Courses for Airport Management Personnel
}

\author{
Henry R. Lehrer, Ph.D. \\ Associate Professor \\ Aeronautical Science Department \\ Embry-Ridale Aeronautical University \\ Daytona Beach, FL 32014 \\ $904-239-6857$
}

27. 


\section{Abstract}

The purpose of this research was to determine and compare the responses of public use airport managers in Arizona, New York, North Carolina, and Ohio to an opinionaire developed for the study. Specific areas investigated were academic courses most desirable for a future airport manager, if a college degree was important, and should the airport manager have experience as a pilot or mechanic.

A review of the related literature indicated that post-secondary education in aviation and airport management was important to practitioners. It was also found that colleges and universities are becoming more involved in aviation education.

The 298 public use airport managers selected for the study included 108 members of the American Association of Airport Executives (AAAE) and 109 ron-AAAE members. Each potential respondent received a survey packet which included the opinionaire and supporting documents.

A total of 103 of the 298 potential respondents returned their opinionaire. The respondents had an average age of 44.2 years, were $91 \%$ male, had been in their present position an average of 8.1 years, and had been in airport management an average of 11.5 years. Additional information from the respondents included their highest academic degree, their major, and the aviation activity and the Federal Aviation Administration facilities at the airport that they were responsible for managing .

28. 
The study revealed that there was agreement among the sample as to whether many of the suggested academic courses should be included in the collegiate preparation of future airport managers. A suggested academic major could include Airport Operation, Airport Internship, Airport Planning, Aviation Law, Aviation Safety, Management, Finance, Economics, Accounting, and Labor Relations. Additional courses that could be considered as a minor or support area include Marketing, Air Transportation, Computer Operation, Business Law, Passenger Operations, Aeronautics, Insurance, Air Traffic Control, Statistics, National Airspace, Air Cargo Handling, Air Carrier operations, and Aviation Insurance.

The importance of a college degree and a recommended college major of business or aviation was determined. The respondents indicated that it was important that the airport manager had experience as à pilot. 


\section{Introduction}

The history of aviation has been full of invention and inrovation. The very act of man attempting to fly has served as a basis for technologjcal developments that spanned centuries. As a result of the first filight and the developments that were to follow, a method of transportation has been born that is like no other in modern history. "Aviation...has achieved a transportation significance not even its pioneers dreamed possible" (Serling, 1983, p. 247).

The dramatic expansion of air travel in recent years has presented the aviation community with numerous problems. One specific challenge is that airports, an extremely important cog in the transportation infrastructure, have developed from grass covered fields "on the edge of town" into small cities that serve thousands of passengers as well as tons of air freight every day. Today's airport has grown from the first two-passenger "terminal," a grass runway, a hangar housing a one man airplane, and one small shovel to what can best be called self contained cities. In 1903, airport management was easy; in the 1980's, as part of an industry built on challenge, it has become the most demanding of the new professions (Smith, Odegard, \& Shea, 1984). The operation of these airports requires management that is cognizant of good business practices and informed about aviation as well. The words of Frederick (1949) that "...it is well for the airport manager to be a flyer, but it is even more important

30. 
that he (sic.) be a businessman" (p. 138) are more significant than ever before in the history of aviation.

Statement of the Problem

Many colleges or universities have students enrolled in two year (Associate degree) and four year (Bachelor's degree) aviation and airport management academic programs. It is the intent of those students to prepare themselves to meet the future workplace demands and challenges of an airport manager by obtaining a post-secondary education. There is little evidence, however, that current courses of study for collegiate aviation and airport management programs have been based on a traditional curriculum model. Some educators are concerned as to whether there is a specific major or course of study that should constitute the academic preparation for future managers of airports in the United States.

Academic preparation as defined by this study included any post-secondary education in aviation management and academic support areas. Specific courses consisted of a composite of higher education academic courses as recommended by collegiate, industry, and government sources as being appropriate for persons wishing to pursue post-secondary majors in aviation management in general and airport management/operation in particular. This study sought to establish whether there was congruence between those courses and the academic preparation as recommended by individuals currently employed as managers of public use airports.

31. 
Significance

The significance of this study is threefold. First, by identifying a validated curriculum model for persons wishing to be future airport managers, a more relevant and effective educational experience is possible. Secondly, colleges and universities that wish to offer academic course work in airport management/operation will have evidence to assist in the development of future programs. Finally, boards of control with airport management positions may find the results of this study helpful in the screening of potential candidates.

The opportunity for academic advisors at both secondary and higher education levels to provide students with a more realistic picture of the academic requirements associated with pursuing a career in airport management/operation may also be helped by the results of this study. There is also a possibility that persons currently employed in aviation management positions may be encouraged by the findings of this study to pursue additional study.

Little data are available from persons in aviation management/operation as to the academic preparation needed to meet the challenges that are routinely encountered in the workplace. By more accurately defining the necessary academic qualifications required of professionals in the field, persons entering this labor force may more realistically plan their academic preparation prior to entering the job market. 
Design of the study

Research Questions

Is there a specific academic curriculum that should be required of students enrolling in higher education airport management programs? How important do airport managers think it is that they are/were pilots and/or mechanics? How important is a college degree to an airport manager? If a college degree is important, what should be the academic major?

Subjects

Subjects for this study were managers of public use airports in Arizona, New York, North Carolina, and Ohio. The selection of these states was based upon the desire to solicit responses from states located in different geographic sections of the United States but yet containing a significant proportion of the nation's airmen, airplanes, and airports. The aviation community of these states represented $8 \%$ of the public use airports, $11 \%$ of the airplanes, and $11 \%$ of the certified airmen of the total United States population (National Association of State Aviation Officials, 1983).

There were two subgroups within the sample. One group of airport managers were members of the American Association of Airport Executives (AAAE) and the other subgroup were not members of the AAAE.

Sample selection

The NASAO Databank '83 (National Association of State Aviation Officials, 1983) stated that there are 12,937 airports

33. 
in the United States of which are publicly owned. To determine the necessary sample size for the study the following formula was utilized (Tuckman, 1978).

$$
N=(z / e)^{2}(p)(1-p)
$$

$\mathbb{N}$ is the necessary sample size, $z$ is the standard score corresponding to a given level, e is the proportion of the sampling error in a given situation, and $\mathrm{p}$ is the estimated proportion of cases in the population. In this study, the confidence level was set at $955(.05)$ or $1.96 \mathrm{z}$, the proportion of sampling error set at $10 \%(.10)$, and the proportion of public use airports in the population determined to be $35 \%$ (.35). The following sample size was calculated.

$$
\begin{aligned}
& N=(1.96 / .10)^{2}(.35)(.65) \\
& N=87
\end{aligned}
$$

It was determined that a sample containing 275-300 public use airports would reduce sampling error and add to the stability of the findings according to Tuckman (1978). Arizona, New York, North Carolina, and Ohio contained 375 public use airports and represented $8 \%$ of the population. The selection of potential respondents and the development of a mailing list utilized who's Who in Airport Management (American Association of Airport Executives, 1985), the Airport Managers List (Arizona Aeronautics Division, 1985), the New York Airport Directory (New York Aviation Bureau, 1984), Airport Managers (North Carolina Department of Transportation, 1985), and the Ohio Airport Directory (Ohio Djvision of Aviation, 1984). 


\section{Instrument}

An opinionaire was developed and tested in Indiana and served as the data gathering instrument for the study. The instrument contained three parts.

The first part, section A, contained thirty-one academic courses that a student could enroll in to prepare for a position as an airport manager or avjation supervisor. These courses were a composite of course offerings from the aviation management curriculum of several institutions of higher learning (Bowling Green State University, 1983, Florida Institute of Technology, 1984, Georgia State University, 1985, and Indiana State University, 1984) and the Airway Science Curriculum Demonstration Project (Office of Personnel Management, 1983b). A Likert scale of 1, 2, or 3 (1- of Little Value, 2 - of Some Value, and 3 Should be Required) was utilized for responses.

The second part, Section B, consisted of questions relative to the importance of a college degree, whether the manager should be/have been a pilot or mechanic, and what academic major is important. A Likert scale of $1,2,3,4$, or 511 - Of No value, 2 - Little value, 3 - Some Value, 4 - Great Value, and 5 - A Must) was utilized for responses. The third part, section C, included demographic questions about each respondent's airport. Procedure

A survey packet containing a cover letter, the opinionaire, a stamped return envelope, and a return postcard were sent to 
each potential respondent. The recipient was encouraged to complete the opinionaire as quickly as possible and return it and the postcard immediately. The postcard contained a code number that indicated that the respondent had returned their survey instrument without specifically identifying their opinionaire. Each potential respondent who had not returned their opinionaire within 14 days was sent a reminder postcard.

The Data

Responses from the returned opinionaire were entered on a microcomputer. Statistical analysis was accomplished with Statistics with Finesse (Bolding, 1984).

Section A and section B were analyzed by sample sub-group (AAAE and non-AAAE) and as a whole. The analysis included the number of responses to each academic course and the percentage of those responses. Section $B$ analysis additionally includes specific cross-tabulations by various sub-groups. Section C includes tallies and percentages with respect to age, gender, academic degree, years in aviation management, and years in present position. The activity and facilities at the respondent's airport was also included in the analysis. Respondents

A total of 103 or $34 \%$ of the opinionaires was returned. Sixteen or $25 \%$ were returned from Arizona, 32 or $36 \%$ from New York, 20 or $31 \%$ from North Carolina, and 28 or $34 \%$ from Ohio. 
Seven or $7 \%$ of the opinionaires were returned without the coded postcards being mailed. The number in parenthesis in all tables indicate percentages.

Table 1

Opinionaire Returns

\begin{tabular}{|c|c|c|c|c|c|c|c|c|c|}
\hline \multirow{3}{*}{ State } & \multicolumn{3}{|c|}{ Total } & \multicolumn{3}{|c|}{ AAAE } & \multicolumn{3}{|c|}{ Non-AAAE } \\
\hline & \multirow{2}{*}{$\begin{array}{c}\text { Sent } \\
N\end{array}$} & \multicolumn{2}{|c|}{ Return } & \multirow{2}{*}{$\begin{array}{l}\text { Sent } \\
\mathrm{N}\end{array}$} & \multicolumn{2}{|c|}{ Return } & \multirow{2}{*}{$\begin{array}{l}\text { Sent } \\
\mathrm{N}\end{array}$} & \multicolumn{2}{|c|}{ Return } \\
\hline & & $\mathrm{N}$ & $\frac{\circ}{0}$ & & $\mathrm{~N}$ & 응 & & $\mathrm{N}$ & 8 \\
\hline Arizona & 63 & 16 & $(25)$ & 31 & 13 & $(43)$ & 32 & 3 & $(09)$ \\
\hline New York & 89 & 13 & $(36)$ & 37 & 20 & $(54)$ & 52 & 12 & $(24)$ \\
\hline North Carolina & 64 & 20 & (31) & 19 & 12 & (63) & 45 & 8 & (18) \\
\hline Ohio & 82 & 28 & (34) & 21 & 9 & (42) & 61 & 19 & (32) \\
\hline Unknown & & 7 & $(07)$ & & 1 & $(02)$ & & 6 & (12) \\
\hline Totals & 298 & 103 & $(34)$ & 108 & 55 & $(50)$ & 190 & 48 & (25) \\
\hline
\end{tabular}

The total population of the study contained two groups, 108 airport managers who were members of the American Association of Airport Executives (AAAE) and 190 who were not members of the organization. Of the 108 AAAE members, 55 or $50 \%$ returned their opinionaires. By state, 13 or $43 \%$ of the AAAE members in Arizona, 20 or $54 \%$ in New York, 12 or 63 in North Carolina, and 9 or $42 \%$ in Ohio responded. One survey packet in Arizona was undeliverable.

The returned opinionaires for non-AAAE respondents totaled 48 or $25 \%$. By state, 3 or $9 \%$ of the non-AAAE members from Arizona responded, 12 or $24 \%$ responded from New York, 8 or $18 \%$ responded from North Carolina, and 19 or $32 \%$ of the potential 
respondents in Ohio returned their opinionaires. Two packets were undeliverable.

The demographic information from the sample provided data on each respondent's gender and age, years in airport management, years in present position, and academic degrees and majors. The gender of the respondents, as indicated in Table 2, was 94 or $91 \%$ male, while 8 or 8 of of the respondents were female.

Table 2

Gender and Age of Respondents

\begin{tabular}{|c|c|c|c|c|c|c|}
\hline & \multicolumn{2}{|c|}{ AAAE } & \multicolumn{2}{|c|}{ NOn-AAAE } & \multicolumn{2}{|c|}{ Total } \\
\hline & $\mathrm{N}$ & $q$ & $N$ & $\%$ & $\mathrm{~N}$ & 용 \\
\hline $\begin{array}{l}\text { Male } \\
\text { Female } \\
\text { Unknown }\end{array}$ & $\begin{array}{r}50 \\
4 \\
1\end{array}$ & $\begin{array}{l}(91) \\
(07) \\
(02)\end{array}$ & $\begin{array}{r}44 \\
4 \\
0\end{array}$ & $\begin{array}{l}(91) \\
(08) \\
(00)\end{array}$ & $\begin{array}{r}94 \\
8 \\
1\end{array}$ & $\begin{array}{l}\left(\begin{array}{ll}9 & 1) \\
(01) \\
(01)\end{array}\right.\end{array}$ \\
\hline $\begin{array}{l}\text { Years } \\
\text { Under } 29 \\
30 \text { to } 39 \\
40 \text { to } 49 \\
50 \text { to } 59 \\
\text { Over } 59 \\
\text { Unknown }\end{array}$ & $\begin{array}{r}4 \\
16 \\
19 \\
11 \\
4 \\
1\end{array}$ & $\begin{array}{l}(07) \\
(30) \\
(35) \\
(20) \\
(07) \\
(02)\end{array}$ & $\begin{array}{r}4 \\
13 \\
12 \\
12 \\
6 \\
1\end{array}$ & $\begin{array}{l}(09) \\
(28) \\
(26) \\
(26) \\
(13) \\
(02)\end{array}$ & $\begin{array}{r}8 \\
29 \\
31 \\
23 \\
10 \\
2\end{array}$ & $\begin{array}{l}(08) \\
(28) \\
(31) \\
(23) \\
(09) \\
(02)\end{array}$ \\
\hline Average & 43. & & 45 & & 44 & \\
\hline
\end{tabular}

Note. The mid-point age for the respondents under 29 years of age and over 59 years of age was arbitrarily set at 24.5 years and 64.5 years.

Eight or $8 \%$ of the respondents were under 29 years of age, 29 or $28 \%$ were between 30 and 39,31 or $31 \%$ were between 40 and 49,23 or $23 \%$ between 50 and 59 , and 10 or $9 \%$ were over age of 59. The average age of the respondents was 44.2 years. 
Table 3 contains the data relative to the respondents' years in airport management and in their present position. In the portion of the table that pertains to the respondents' years in airport management, one $A A A E$ and three non-AAAE respondents did not respond.

Table 3

Respondent's Years in Airport Management and Present Position

\begin{tabular}{|c|c|c|c|c|c|c|c|c|c|c|c|c|}
\hline \multirow{3}{*}{ Years } & \multicolumn{6}{|c|}{ Airport Management } & \multicolumn{6}{|c|}{ Present Position } \\
\hline & \multicolumn{2}{|c|}{ AAAE } & \multicolumn{2}{|c|}{$\begin{array}{l}\text { Non- } \\
\text { AAAE }\end{array}$} & \multicolumn{2}{|c|}{ Total } & \multicolumn{2}{|c|}{ AAAE } & \multicolumn{2}{|c|}{$\begin{array}{l}\text { Non- } \\
\text { AAAE }\end{array}$} & \multicolumn{2}{|c|}{ Total } \\
\hline & $\mathrm{N}$ & $\%$ & $\mathrm{~N}$ & 음 & $\mathrm{N}$ & \% & $\mathrm{N}$ & \% & $\mathrm{N}$ & \% & $\mathrm{N}$ & 음 \\
\hline Under 5 & 7 & (13) & 15 & $(34)$ & 22 & $(22)$ & 24 & $(45)$ & 15 & $(34)$ & 39 & $(40)$ \\
\hline 5 to 10 & 17 & (31) & 11 & (25) & 28 & $(22)$ & 18 & (34) & 13 & $(30)$ & 31 & (32) \\
\hline 11 to 15 & 15 & $(28)$ & & (18) & 23 & $(23)$ & 7 & (13) & 9 & $(20)$ & 16 & $(16)$ \\
\hline 16 to 20 & 6 & (11) & 3 & (07) & 9 & $(16)$ & 2 & $(04)$ & 2 & $(05)$ & 4 & $(04)$ \\
\hline Over 20 & 9 & $(17)$ & 7 & (16) & 16 & $(16)$ & 2 & (04) & 5 & (11) & 7 & $(07)$ \\
\hline Unknown & 1 & $(02)$ & 3 & $(07)$ & 4 & $(03)$ & 2 & $(04)$ & 3 & $(07)$ & 5 & $(05)$ \\
\hline Average & 12 . & & 10. & & 11. & & 7 & & 9 & 4 & 8 & 1 \\
\hline
\end{tabular}

Note. The mid-point for respondents with over 20 years in a category was arbitrarily set at 25 years and with under 5 years at 2.5 years.

Seven or $13 \%$ of the AAAE members had less than 5 years of airport management experience while 15 or $34 \%$ of the non-AAAE respondents had been in airport management for a similar period. The AAAE respondents had an average experience level in airport management of 12.5 years, the non-AAAE respondents of 10.3 years, and the total respondents had an average of 11.5 years of experience. 
The years of experience of the respondents in their present position are also contained in Table 3. A total of five or $5 \%$ did not respond. The AAAE respondents had an average experience level in their present position of 7.0 years, the non-AAAE respondents of 9.4 years, and the total respondents had an average of 8.1 years. Forty-two or $78 \%$ of the AAAE members had been in their present position for 10 years of less while 28 or $64 \%$ of the non-AAAE respondents had held their present position for a similar period.

The highest academic degree of the respondents is reported in Table 4. All AAAE members had at least a two year degree while 11 or $23 \%$ of the non-AAAE members had no post-secondary degree. Fifty-two or $49 \%$ of the respondents had a Bachelor's degree and 16 or $29 \%$ of the AAAE respondents had a Master's degree. One AAAE respondent had a doctorate.

Table 4

Highest Academic Degree of Respondents

\begin{tabular}{|c|c|c|c|c|c|c|}
\hline & \multicolumn{2}{|r|}{ AAAE } & \multicolumn{2}{|c|}{ Non-AAAE } & \multicolumn{2}{|c|}{ Total } \\
\hline & $\mathrm{N}$ & 8 & $\mathrm{~N}$ & 告 & $\mathrm{N}$ & 8 \\
\hline High School & 0 & $(00)$ & 11 & (23) & 11 & (10) \\
\hline Two Year & 10 & $(18)$ & 8 & $(17)$ & 18 & (17) \\
\hline Bachelor's & 28 & $(51)$ & 24 & $(50)$ & 52 & (49) \\
\hline Master's & 16 & (29) & 4 & $(09)$ & 29 & (18) \\
\hline Doctorate & 1 & $(02)$ & 0 & $(00)$ & 1 & (01) \\
\hline Unknown & 0 & $(00)$ & 1 & $(02)$ & 1 & $(04)$ \\
\hline
\end{tabular}

40. 
Academic Course Analysis

The data in Table 5 show the responses to the questions that were contained in Section A of the opinionaire. A three point Likert scale $(1$ - of Little Value, 2. - of Some value, and 3 Should be Required) was utilized and respondents were asked to indicate whether they thought a specific academic course should be included in the major or support area of a future airport manager's academic preparation. Information in this table reports the percentage of the total response in each category.

The academic courses that are reported as "should be required" by more than 50\% of the total respondents include Management (96\%), Airport Operation (93\%), Airport Internship (87\%), Finance (84\%), Airport Planning (82\%), Aviation Law (79\%), Aviation Safety (63\%), Economics (56\%), Accounting (54\%), and Labor Relations (52\%). The AAAE respondents, in addition to the academic courses previously mentioned, indicated that Air Transportation (58\%) "should be required." The non-AAAE respondents indicated that Aeronautics (54\%) "should be required."

Academic courses that were indicated as "of little value" by over $50 \%$ of the respondents include Electronics in Aviation (52\%) and Man and Technology (56\%). The AAAE respondents, in addition to the academic courses previously mentioned, indicated that Instrument Flight (59\%) was "of little value," while non-AAAE respondents stated that Aviation History (65\%) and Travel and Tourism (60\%) were "of little value" to a future airport manager. 
Table 5

Ranking of Academic Courses by Percentage of Responses

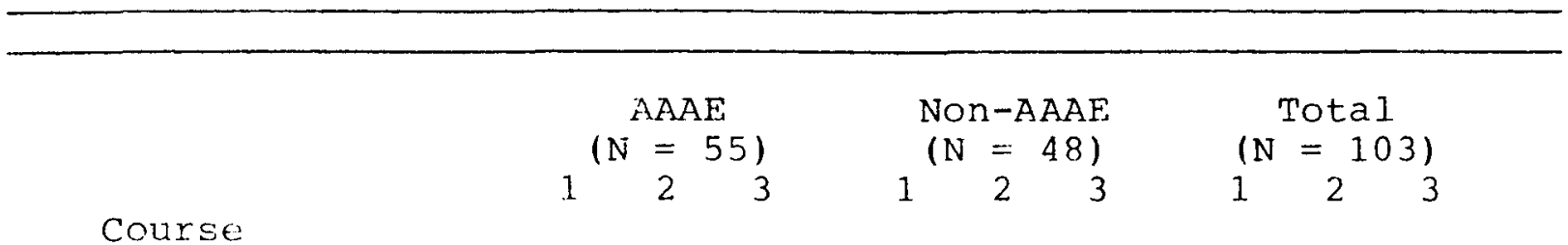

\begin{tabular}{|c|c|c|c|c|c|c|c|c|c|}
\hline Management & 00 & 02 & 98 & 02 & 04 & 94 & 01 & 03 & 96 \\
\hline Airport Operation & 00 & 05 & 95 & 02 & 07 & 91 & 01 & 05 & 93 \\
\hline Airport Internship & 00 & 10 & 90 & 02 & 13 & 85 & 01 & 12 & 87 \\
\hline Finance & 00 & 10 & 90 & 02 & 17 & 81 & 01 & 15 & 84 \\
\hline Airport Planning & 00 & 13 & 87 & 02 & 24 & 74 & 01 & 17 & 82 \\
\hline Aviation Law & 00 & 15 & 85 & 06 & 23 & 71 & 03 & 18 & 79 \\
\hline Aviation Safety & 14 & 31 & 55 & 06 & 21 & 73 & 11 & 26 & 63 \\
\hline Economics & 05 & 33 & 62 & 17 & 33 & 50 & 11 & 34 & 56 \\
\hline Accounting & 09 & 31 & 60 & 06 & 48 & 46 & 08 & 38 & 54 \\
\hline Labor Relations & 04 & 31 & 65 & 04 & 58 & 38 & 04 & 44 & 52 \\
\hline Business Law & 13 & 24 & 63 & 17 & 52 & 31 & 14 & 38 & 48 * \\
\hline Air Transportation & 06 & 36 & 58 & 15 & 52 & 33 & 10 & 43 & $47 *$ \\
\hline Aeronautics & 20 & 48 & 32 & 12 & 33 & 54 & 17 & 41 & 43 * \\
\hline Insurance & 17 & 54 & 29 & 17 & 35 & 48 & 16 & 45 & $38 *$ \\
\hline Passenger Operations & 14 & 44 & 42 & 13 & 61 & 26 & 14 & 51 & 35 * \\
\hline Computer Operations & 04 & 49 & 47 & 20 & 63 & 17 & 11 & 55 & 34 * \\
\hline Air Traffic Control & 18 & 53 & 29 & 16 & 44 & 40 & 18 & 49 & 34 * \\
\hline Aviation Insurance & 31 & 40 & 29 & 20 & 40 & 40 & 26 & 41 & 34 * \\
\hline Marketing & 04 & 65 & 31 & 13 & 54 & 33 & 08 & 59 & $33 *$ \\
\hline National Air Space & 20 & 47 & 33 & 25 & 44 & 31 & 2.1 & 47 & $32 *$ \\
\hline Air Carrier Operation & 22 & 51 & 27 & 21 & 48 & 31 & 24 & 47 & 29 * \\
\hline Statistics & 05 & 62 & 33 & 29 & 52 & 19 & 17 & 57 & 26 * \\
\hline Meteorology & 41 & 52 & 07 & 26 & 43 & 31 & 33 & 48 & 19 \\
\hline Air Cargo Handling & 20 & 67 & 13 & 26 & 55 & 19 & 23 & 62 & $16^{*}$ \\
\hline \multicolumn{10}{|l|}{ Aviation weather } \\
\hline Services & 38 & 51 & 11 & 24 & 59 & 17 & 31 & 55 & 14 \\
\hline Air Carrier Economics & 18 & 67 & 15 & 39 & 50 & 11 & 28 & 60 & 12 \\
\hline Travel and Tourism & 29 & 58 & 13 & 60 & 31 & 09 & 43 & 46 & 11 \\
\hline Instrument Flight & 59 & 39 & 02 & 37 & 46 & 17 & 49 & 41 & 10 \\
\hline Man and Technology & 48 & 41 & 11 & 64 & 33 & 03 & 56 & 37 & 07 \\
\hline \multicolumn{10}{|l|}{ Electronics in } \\
\hline Aviation & 59 & 40 & 01 & 44 & 48 & 08 & 52 & 43 & 05 \\
\hline
\end{tabular}

Note. * indicates that the combined total of columns 2 and 3 is equal to or greater than $75 \%$. 
The asterisk in Table 5 is used to show the academic courses that $75 \%$ or more of the respondents indicated were "of some value" or greater to a future airport manager. These courses and the percent of such response include Marketing (92\%), Air Transportation (90\%), Computer Operations (89\%), Business Law $(86 \%)$, Passenger Operations (86\%), Aeronautics (84\%), Insurance (83\%), Air Traffic Control (83\%), Statistics (83\%), National Airspace (79\%), Air Cargo Handling (78\%), Air Carrier Operations (76\%), and Aviation Insurance (75\%).

Supplementary information

Table 6 contains the data relative to the responses to the question of the importance of a college degree to a future airport manager. Sixty-nine or $71 \%$ of the respondents indicated that a college degree is of "great value" or "a must." This Table 6

Responses to the Importance of a College Degree

\begin{tabular}{|c|c|c|c|c|c|c|c|c|c|c|}
\hline \multirow{2}{*}{ Degree } & \multicolumn{2}{|c|}{$\begin{array}{l}\text { Of No } \\
\text { Value }\end{array}$} & \multicolumn{2}{|c|}{$\begin{array}{l}\text { Little } \\
\text { Value }\end{array}$} & \multicolumn{2}{|c|}{$\begin{array}{l}\text { Some } \\
\text { Value }\end{array}$} & \multicolumn{2}{|c|}{$\begin{array}{l}\text { Great } \\
\text { Value }\end{array}$} & \multicolumn{2}{|c|}{$\begin{array}{c}\text { A } \\
\text { Must }\end{array}$} \\
\hline & $\mathrm{N}$ & $\frac{7}{0}$ & $\mathrm{~N}$ & $\frac{\circ}{0}$ & $\mathrm{~N}$ & $\%$ & $\mathrm{~N}$ & 8 & $\mathrm{~N}$ & $\frac{g}{0}$ \\
\hline A Degree & 3 & $(03)$ & 2 & $(02)$ & 25 & $(25)$ & 31 & $(32)$ & 38 & (39) \\
\hline Associate & 5 & $(05)$ & 19 & $(20)$ & 51 & $(52)$ & 13 & (13) & 9 & (09) \\
\hline Bachelor's & 4 & $(04)$ & 2 & $(02)$ & 26 & $(25)$ & 35 & (34) & 34 & (34) \\
\hline Master's & 12 & $(12)$ & 23 & $(23)$ & 37 & $(37)$ & 26 & $(26)$ & 2 & $(02)$ \\
\hline Doctorate & 36 & $(36)$ & 36 & $(36)$ & 16 & (16) & 12 & (12) & 0 & $(00)$ \\
\hline
\end{tabular}

43. 
average came from 44 or $85 \%$ of the AAAE and 25 or $53 \%$ of the non-AAAE members indicating this response. None of the AAAE members indicated that a college degree would be "of no value" or of "little value" while 5 or $10 \%$ of the non-AAAE participants indicated either a "no value" or "little value" response.

The responses to the question of the recommended college major for an airport manager are shown in Table 7. Forty-five respondents reported that business was the recommended major. A major in aviation was recommended by 25 respondents. No percentages are reported in Table 7 because numerous opinionaires either included no response or more than one response to this question.

Table 7

Responses to Recommended Academic Major

\begin{tabular}{lccc}
\hline & & & \\
\hline \multicolumn{1}{c}{ Major } & NAA & & Total \\
& & & \\
\hline Business & 29 & 16 & 45 \\
Aviation & 19 & 6 & 25 \\
Engineering & 3 & 3 & 6 \\
Not Important & 4 & 2 & 6 \\
Psychology & 1 & 1 & 1 \\
Natural Science & 0 & 1 & \\
\hline
\end{tabular}

The importance of the airport manager having experience as a pilot or a mechanic is reported in Table 8 . Fifteen or $28 \%$ of the AAAE members indicated that being a pilot was of "great value" or "a must" while 25 or $50 \%$ of the non-AAAE members indicated a similar response. Whether the airport manager should 44. 
have experience as a mechanic was indicated as being "of no value" or of "little value" by 68 or $66 \%$ of the total.

Table 8

Responses to the Importance of Being a Pilot or Mechanic

\begin{tabular}{|c|c|c|c|c|c|c|c|c|c|}
\hline \multicolumn{2}{|c|}{$\begin{array}{l}\text { Of No } \\
\text { Value }\end{array}$} & \multicolumn{2}{|c|}{$\begin{array}{l}\text { Little } \\
\text { value }\end{array}$} & \multicolumn{2}{|c|}{$\begin{array}{l}\text { Some } \\
\text { Value }\end{array}$} & \multicolumn{2}{|c|}{$\begin{array}{l}\text { Great } \\
\text { Value }\end{array}$} & \multicolumn{2}{|c|}{$\begin{array}{c}\text { A } \\
\text { Must }\end{array}$} \\
\hline $\mathrm{N}$ & $\%$ & $\mathrm{~N}$ & $\frac{\circ}{0}$ & $\mathrm{~N}$ & 웅 & $\mathrm{N}$ & $\frac{8}{8}$ & $\mathrm{~N}$ & 움 \\
\hline
\end{tabular}

AAAE

$\begin{array}{lrlrlllllll}\text { A Pilot } & 7 & (13) & 13 & (24) & 20 & (36) & 12 & (22) & 3 & (06) \\ \text { A Mechanic } & 14 & (26) & 28 & (51) & 11 & (20) & 2 & (03) & 0 & (00)\end{array}$

NON-AAAE

$\begin{array}{lllrlrlrlll}\text { A Pilot } & 3 & (06) & 2 & (04) & 19 & (40) & 18 & (38) & 6 & (12) \\ \text { A Mechanic } & 6 & (12) & 20 & (42) & 17 & (35) & 4 & (08) & 1 & (02)\end{array}$

Total

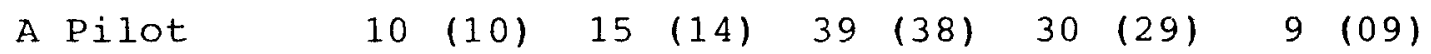

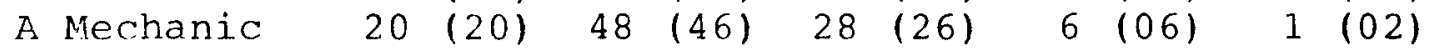

\section{Conclusions}

This research is an initial effort in determining an academic curriculum for future airport managers. Due to the small number of opinionaire returns, an extensive statistical analysis would be both non-productive and possibly misrepresentative of the population. The reader must, accordingly, use caution in the interpretation of any information. The conclusions that follow are based upon the findings from specific questions contained in the opinionaire

45. 
developed for this study and upon what limited literature was available. The following conclusions were drawn:

1. A college degree for a future airport manager may become more important. There was strong support (71\%) of the respondents indicated that a college degree was "of great value" or "a must") for a college degree among the sample respondents.

2. A Bachelor's degree is perhaps the minimum degree necessary or desirable for an airport manager. Sixty-nine or 68\% of the respondents indicated that a Bachelor's degree was of "great value" or "a must." A combination of aviation and business appeared to constitute the best academic major.

3. The content of the following academic courses was recommended by respondents for the major in an airport management curriculum. Academic courses that received more than $50 \%$ group response indicating that each "should be required" for a future airport manager nay have enough support to be considered as a major. These courses included Managemert (96\%), Airport Operations (93\%), Airport Internship (79\%), Aviation Safety (63\%), Economics (56\%), Accounting (54\%), and Labor Relations $(52 \%)$.

4. A number of academic courses could be considered as a minor or support area so as to broaden the field of emphasis for a future airport manager. These courses were rated as of "some value" or "should be required" by over $75 \%$ of the respondents. The courses included in this group are Marketing (92\%), Air

46. 
'Iransportation (90\%), Computer Operation (89\%), Business Law (86\%), Passenger Operations (86\%), Aeronautics (84\%), Insurance (83\%), Air Traffic Control (83\%), Statistics (83\%), National Airspace (79\%), Air Cargo Handling (78\%), Air Carrier Operation (76\%), and Aviation Insurance (75\%).

5. The airport manager should have experience as a pilot. Seventy-eight percent of the respondents indicated that being a pilot was "of some value" or greater in the background of an airport manager.

6. The airport manager does not need to be or have been a mechanic according to the respondents of this study. There was little support for this among participants.

\section{$\underline{\text { Recommendations }}$}

1. The University Aviation Association should consider the findings of this research as a starting point for further study of collegiate airport management programs.

2. The American Association of Airport Executives might disseminate the findings of this study to the membership of the organization.

3. The Federal Aviation Administration could undertake a study to determine the number of positions that are actually available for graduates of aviation management programs.

47. 
References

American Association of Airport Executives. (1985). Who's who in airport management. Washington, DC: Author.

Arizona Aeronautics Division. (1985). Airport managers list.

Phoenix, AZ: Department of Transportation.

Bolding, J. (1984). Statistics with finesse. Fayetteville, AR: Author.

Bowling Green State University. (1983). Undergraduate catalog. Bowling Green, $\mathrm{OH}$ : Author.

Florida Institute of Technology. (1984). Catalogue. Melbourne, FL: Author.

Frederick, J. (1949) . Airport management. Chicago, IL:

Richard Irwin.

Georgia State University (1985) - Undergraduate catalog.

Atlanta, GA: Author.

Indiana State University. (1984). Bulletin. Terre Haute, IN: Author.

National Association of State Aviation Officials. (1983). Databank '83. Washington, DC: Author.

New York Aviation Bureau. (1984). New York state airport

directory. Albany, NY: Department of Transportation. North Carolina Department of Transportation. (1985). Airport managers. Raleigh, NC: Author. 
Office of Personnel Management. (1983, July 15). Airway science curriculum: Approval of demonstration project final plan. (Federal Register Vol. 48, No. 137, pp. 32490-32499). Washington, DC: U.S. Government Printing Office.

Ohio Division of Aviation. (1984). Ohio airport directory. Columbus, $\mathrm{OH}$ : Department of Transportation. Serling, R. (1983). Air transportation: Commercial aviation. In P. W. Devore (E.d.), Introduction to transportation (pp. 247-264). Worcester, MA: Davis. Tuckman, B. (1978). Conducting educational research. New York, NY: Harcourt Brace Jovanovich. 